\title{
An Analytical Survey on the Learning Performance of the Lecturers at the Faculty of Education
}

\author{
Titin I. Pratiwi ${ }^{1, *}$ Evi Winingsih ${ }^{1}$ Kartika Rinakit Adhe ${ }^{1}$ \\ ${ }^{1}$ Faculty of Education, Universitas Negeri Surabaya \\ *Corresponding author. Email: titinindahpratiwi@unesa.ac.id

\begin{abstract}
Learning Evaluation and monitoring are the soul of a learning process. They are vehicles used to improve the learning process. Institution Performance Education personnel are required to have international standards. One of the weapons that are used to compete is by applying the ISO 9001: 2015 standard. This study aims to evaluate the performance of lecturers, especially the learning process carried out by lecturers at the Faculty of Education. This study uses an analytical survey method. The instrument was developed by referring to ISO 9001: 2015. The subjects in this study were lecturers at the Faculty of Education. The study results found that the most findings were in the learning evaluation domain of $68 \%, 21 \%$ in learning planning, and $11 \%$ in the learning implementation domain. Several reasons led to the discovery. This data will be used as one of the reviews to follow up on learning in FIP.
\end{abstract}

Keywords: Evaluation, Learning, Standards.

\section{INTRODUCTION}

The development on higher education which is formulated in the strategic planning of the Ministry of National Education stresses on the the availability and affordability the qualified educational services, relevant, international competitiveness, and equal by using six strategies as follows: (i) provision of competent lecturers; (ii) the improvement of university management quality; (iii) the availability of researchbased data and information which has quality standard for higher education and implementation of higher education accreditation; (iv) provision and improvement of medium and infrastructure for the implementation of qualified and competitive university educational systems which spread evenly in all provinces; (v) improvement of publication of research results and public services which are qualified, internationally competitive, and relevant to the nation needs; and (vi) provision of subsidy for improvement of affordability of qualified and competitive university educational services which spread evenly in all provinces [1],[2].

In this globalization era and the MEA's fulfillment make the university must compete with the global university. Many people assume that global universities are better than local universities[3]. It is a fact that many Indonesian students study abroad. This phenomenon is a challenge for the local university to improve their quality to compete globally. International standards must be applied in all departments and faculties of local universities; one of them is the Faculty of Education of Surabaya State University.

The Faculty of Education of Surabaya State University standardized ISO 9001: 2015, a reputable international standardization. Reasonable internal quality assurance for all focuses must be conducted to sustain the ISO standard.

The quality of the educational system in a university is a crucial problem that must be improved continuously by making any efforts. Principally, the quality of the educational system in a university can be measured from the preparation, implementation, and Evaluation of the learning system[4],[5]. An appropriate evaluation and monitoring of the learning system will result in competent alumni in their fields.

The preparation of learning can be measured based on the learning design and teaching materials prepared by lecturers. Both of them will influence the learning processes of the lecturers. The implementation of learning processes is also an important key success of the learning processes. It includes subjects, language, learning approaches, learning media, punctual and character-building processes[6],[7],[9]. 
The last factor is the Evaluation of learning processes. It is used to check whether or not the learning process is successful[8]. Therefore, the results of the Evaluation can be used for learning process improvement.

The monitoring and Evaluation in the Faculty of Education are conducted regularly at the end of the semester. The activities are Evaluation on the curriculum and curriculum's documents related to Indonesia Qualification Framework (KKNI) and its implementation in learning by constructing Semester Learning Planning include suitability in implementation (subjects, methods, dan literature)[6].

Evaluation is a key success for improving the learning quality and alumni quality. Therefore, research on the Evaluation and monitoring of learning processes is critical to analyze the result further. An analytical performance survey was conducted on the faculty's lecturers in the even semester academic year 2017/ 2018.

\section{METHODS}

The survey design describes some trends, behavior, or opinion of the population quantitatively by taking samples.

A cross-sectional design is chosen. In this method, the measurement and observation are conducted simultaneously at one time. The survey results are used to test the relationship among variables and conclude the relationship.

This analytical survey research utilizes instruments of learning evaluation standards from ISO 9001: 2015. It is intended to analyze the relationship between lecturers' performance to ISO 9001: 2015 standard. The research survey is done one time. It means that the observation and questionnaire are only proven one time. The research objects are lecturers in FIP.

The population is all subject research [10],[11],[12]. The population in this study is all lecturers in the FIP. Samples are taken from the population. Samples are part of the population [10],[11],[12].

In this research, samples are chosen based on quota. The choice is not based on area or strata but based on a determined number or quota. The number of quotas is determined by negotiation the researcher with the head of departments. Therefore, 16 lecturers were chosen, two from each department in FIP.

Data analysis is conducted based on learning domain. Mean is calculated for each domain; i.e. planning, implementation, and evaluation of learning processes. The equation is as follow:
Mean:

$\mathbf{X}=\left(\mathbf{x}_{1}+\mathbf{x}_{2}+\ldots+\mathbf{x}_{\mathbf{n}}\right) / \mathbf{n}$

Remarks:

1. $\mathrm{X}=$ mean

2. $\mathrm{x}_{1}=$ value of data number 1

3. $\mathrm{x}_{2}=$ value of data number 2

4. $x_{n}=$ value of data number $n$

5. $\mathrm{n}=$ Number of data

\section{RESULTS AND DISCUSSION}

A Diagram of data analysis of 3 learning domains is presented in Figure 1.

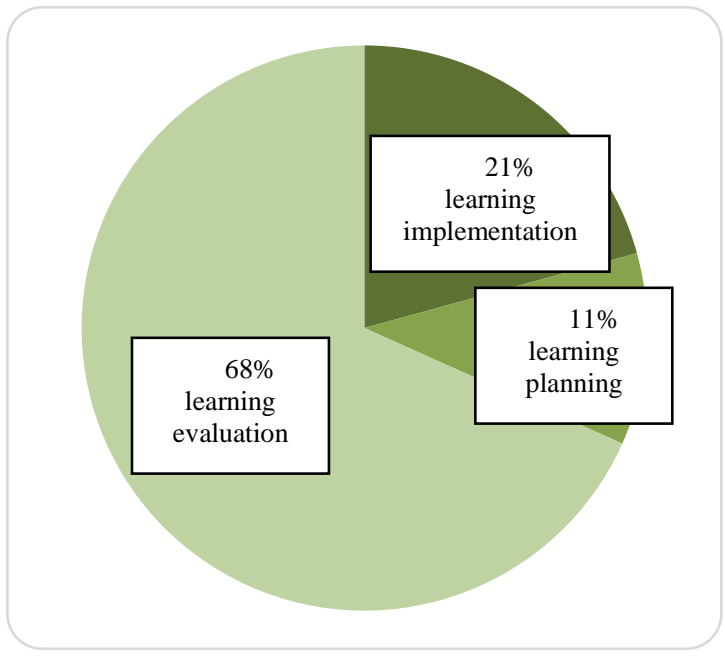

Figure 1 Data analysis diagram

Survey data shows that the learning evaluation domain is dominant, i.e., 68\%. The implementation domain and planning domain comprises $21 \%$ and $11 \%$, consecutively.

There are many findings in learning evaluation. They are (i) administrative works at all departments is weak, (ii) less commitment to finding replacement schedule, (iii) less discipline in marking and returning students works (assignment, exams).

Weak administrative works in the departments are because some quality assurance unit (UPM) members do not have evaluation forms such as validation form for exam and form for marking rubric of the exam. Moreover, there is some unsynchronized procedure in approving the examination problems. The person who approves at SIAKADU (a system information academic and education) the problems prepared by lecturers is a UPM member. However, this person does not 
understand whether or not the problems have contained higher thinking since he or she is not necessarily a lecturer with the same expertise as the lecturer who created the problem. Therefore, it is better than approving the examination problems conducted by the lecturer, a member of the subject course team.

The problem of less commitment to finding a replacement schedule can be seen from unsynchronized between subject and syllabus or semester learning planning. Lecturers gave lectures for replacement mainly at the end of the semester.

Less discipline in marking and returning students' works (assignments, exams) happens due to too busy doing many other works.

On the website of USAID is written that lecturers must own seven pedagogic competencies. One of them is marking and Evaluation. These competencies are looked easy. However, it is not easy to be implemented. It only needs commitment and punctuality. The finding in the FIP is that for $50 \%$ of departments on the evaluation domain, and most lecturers do not return the student's works and assignments soon or on time. The lecturers themselves must correct it to make them become good lecturers who commit to the vision and mission of the faculty.

\section{CONCLUSION}

From the research results, it can be concluded that the dominant problem in the learning process in the FIP is the evaluation domain that holds $68 \%$. During implementation, domain and planning domain comprises $21 \%$ and $11 \%$, consecutively. The main problems in the evaluation domain are that administrative works at all departments are weak, there is less commitment to finding a replacement schedule, and there is less discipline in marking and returning students' works (assignments, exams). The lecturers need to correct themselves to become committed, and good lecturers as the vision and mission of the faculty stated.

\section{REFERENCES}

[1] Peraturan Pemerintah No 12 tahun 2012, Jakarta, 2012.

[2] Peraturan Pemerintah No. 17 tahun 2012, Jakarta, 2012.

[3] K.Daniel, Office of Educational Research and Improvement, 1994.

[4] G.Sax, Principle of Educational and Psychological Measurement Evaluation 2nd, Wordsworth Publishing Company Belmont, 1980.

[5] M. Scriven, The Methodology of Evaluation, in Perspective of Curriculum Evaluation, Chicago: Rand McNally and Company, 1967.
[6] F. Y. W. Tayibnapis, "Evaluasi Program Pembelajaran," Jurnal Ilmu Pendidikan, pp.1-16, 2000

[7] Z. Arifin, Evaluasi Pembelajaran, Direktorat Jenderal Pendidikan Islam Kementerian Agama. 2012

[8] S. Alexander and J.G. Hedberg, "Evaluating Technology-Based Learning - Which Model," Interactive Multimedia in University Education: Designing for Change in Teaching and Learning, pp.233-244, 1994.

[9] T. Eckes, "Rater types in writing performance assessments: A classification approach to rater variability," Language Testing, vol. 25, 2008 , https://doi.org/10.1177/0265532207086780

[10] M.A. Morissan, Metode Penelitian Survey. Jakarta: Kencana, 2014

[11] M. Singarimbu., and S. Effendi, Metode Penelitian Survei. Yogyakarta: LP3ES, 1995.

[12] S. Arikunto., Prosedur Penelitian Suatu Pendekatan, Jakarta: Rineka Cipta, 2006. 